\title{
Brand Experience: A Review of 39 Years of Research Development
}

\author{
Moh. Darus Salam a ${ }^{1}$ iD \\ ${ }^{a}$ Faculty of Vocational Studies, Universitas Airlangga, Surabaya
}

\begin{abstract}
APA Citation:
Salam, M.D. (2020). Brand experience: a review of 39 years of research development. TIJAB (The International Journal of Applied Business), 4(2), 157-167.

Submission Date: 17/9/2020

Acceptance Date: $13 / 11 / 2020$
\end{abstract}

\begin{abstract}
This study explored the trends of academic research on brand experience using bibliometric methods. The exploration included statistical data from published articles on Scopus database. Relevant articles were extracted from Scopus indexed journals using keywords collected through online survey. The analysis covered 1,920 articles in 484 journals published between 1981 and 2020. This study recognized prominent scholars, institutions, sources as well as the most cited articles of brand experience research. Some important and most used keywords in brand experience publications were also identified. Study findings indicated growing interest in brand experience research despite publication absence in some of the early years of its development. The most cited article was written by Fournier in 1998 entitled "Consumers and Their Brands: Developing Relationship Theory in Consumer Research." Journal of Business Research was the most cited journal in the area with 5,010 citations and has become the most productive journal with 83 titles.
\end{abstract}

Keywords: brand experience; customer experience; experiential marketing; research trend; bibliometric analysis

This is an open access article under the $\mathrm{CCBY-NC-SA}$ license.

\section{Introduction}

Marketing discussions, both academically and practically, have shifted from pragmatic point of view such as product benefit and price to other intangible aspects such as relationship and engagement (Iglesias and Singh, 2011; Nysveen et al., 2013). Customers no longer buy goods and services per se, but also consider the experience they can get through the product (Morrison and Crane, 2007; Nysveen et al., 2013). Several constructs on experience have been introduced such as Holbrook and Hirschman's consumption experience (1982), Hui and Bateson's service experience (1991), Kerin et al.'s shopping experience (1992), Hoch's product experience (2002), Gentile et al.'s customer experience (2007), and Brakus et al.'s brand experience (2009). Although the latter concept was considered as the most

\footnotetext{
${ }^{1}$ Corresponding author.

E-mail address: m.darus@vokasi.unair.ac.id
} 
comprehensive idea of experience (Nysveen et al., 2013; Zarantonello and Schmitt, 2010), only a few bibliometric studies have been conducted on the subject.

Brand experience is considered new topic among well-known concepts in marketing (Khan and Rahman, 2015). Khan and Rahman (2015) stated the inception of "brand experience" term goes back to the study of Ortmeyer and Huber in 1991, notwithstanding, argued it was defined by Brakus et al. in 2009 through an article published on Journal of Marketing entitled Brand Experience: What Is It? How Is It Measured? Does It Affect Loyalty?

In the article, Brakus et al. (2009) contended brand experience construct was distinct from, but also related to, other brand constructs such as brand attitudes, brand involvement, brand attachment, customer delight, and brand personality. They described brand experience as "sensations, feelings, cognitions, and behavioural responses evoked by brand-related stimuli that are part of a brand's design and identity, packaging, communications, and environments" [Brakus et al., (2009), p.3].

Scholars have been covering the topic of brand experience in many studies to confirm, improve and refine the construct. However, limited bibliometric study on brand experience creates insufficient information on those study areas and research settings. Little is known about its current state of development and no previous studies confirmed where this subject was headed (Khan and Rahman, 2015). While a current content analysis study by Khan and Rahman (2015) suggested plausible direction of brand experience future research, the analysis was based on limited number of reference (i.e. 73 articles published in 38 journals).

The most recent bibliometric evaluation on brand experience was written by Zha, Melewar, Foroudi, $\&$ Jin (2020). Their work attempted to go further than antecedent-consequence framework presented in Khan and Rahman (2015) by deploying a combination of high citation and co-citation metrics. Their analysis was based on 136 articles extracted from Web of Science database within 17-year old period. While several literature reviews on brand experience have been published to satisfy the imperative needs for deeper point-of-view towards brand experience research development, they argued brand experience knowledge structure from bibliometric standpoint was unavailable.

Considering the wide span since brand experience outset, this paper fills the gap by presenting longer publication period and incorporating larger number of articles into the analysis. It offers a whole spectrum of development pattern on brand experience and some milestones during the process are highlighted. The paper also balanced the scientific frame of reference as the data were extracted from Scopus database. Hence, this paper attempts to satisfy two primary functions: (1) to provide trends on brand experience research development, (2) to complement and complete current bibliometric studies on brand experience available to the community.

\section{Methodology}

An online survey was conducted to scholars whose articles were related to brand experience and published on Scopus database. Their contact addresses were collected from their own articles. Respondents came from different designations, ranging from lecturer to senior lecture. Specifically, 33\% of respondents identified themselves as professors, $27 \%$ as senior lecturer/assistant professor, $13 \%$ as lecturer, and $3 \%$ as $\mathrm{PhD}$ candidates. They were asked to verify a list of keywords related to brand experience and suggest additional keywords they deemed relevant to the subject. The survey managed to collect $100 \%$ of target response. No less than 30 respondents rated the list of keywords and submitted additional keywords of their choice, creating database of important words in brand experience publication.

According to respondents' responses when selecting relevant keywords from the list, not all of the keywords were considered relevant. Based on survey results, the chosen and recommended keywords 
were as follows: brand experience, customer experience, consumer experience, brand relationship, experiential branding, experiential marketing, customer engagement, brand management, brand strategy, shopping experience, and brand engagement.

Those keywords were used as the basis of this study and to extract articles from Scopus database. Scopus is chosen for it is one of the biggest research databases and has tools to access and manage publications' indicators (Gaviria-Marin et al., 2018). The database is also considered as a valid and reliable academic publication source (Villa et al., 2018). Retrieved articles were analyzed using bibliometric methods of which the development of certain field is accessed based on scholars' research outputs and influence (Elisabetta et al., 2018; Geng, et al., 2017).

Brand experience is the first keyword used to create a pool of articles within subject interest bracket. This step resulted in 6,498 documents in Scopus database as of October 4, 2020. The phrase was intentionally put without quotation mark to generate results as broad as possible. Scopus would return all documents where brand and experience appear together or separately in the keywords, abstract, or title. Further, an equation consisted of quoted survey-verified keywords was applied to collect relevant articles from the pool and resulted in 2,902 documents.

Unfortunately, not all results from previous step were closely related and further refinement was required. Out of all articles, only those published under five related categories were included (i.e. business, management, accounting; social sciences; economics, econometrics and finance; psychology; and multidisciplinary). Other categories such as engineering, material sciences and computer science were excluded for they were out of the range of the subject interest. In addition, type of document was specified to be article only. The articles were also set to be in English and the publication stage was final; hence, eliminated those articles in press. These final steps resulted in 1,925 documents. The limit of publication years has not been specifically set in order to get results that reflected the entire publication span. The methodology of this study can be illustrated below:

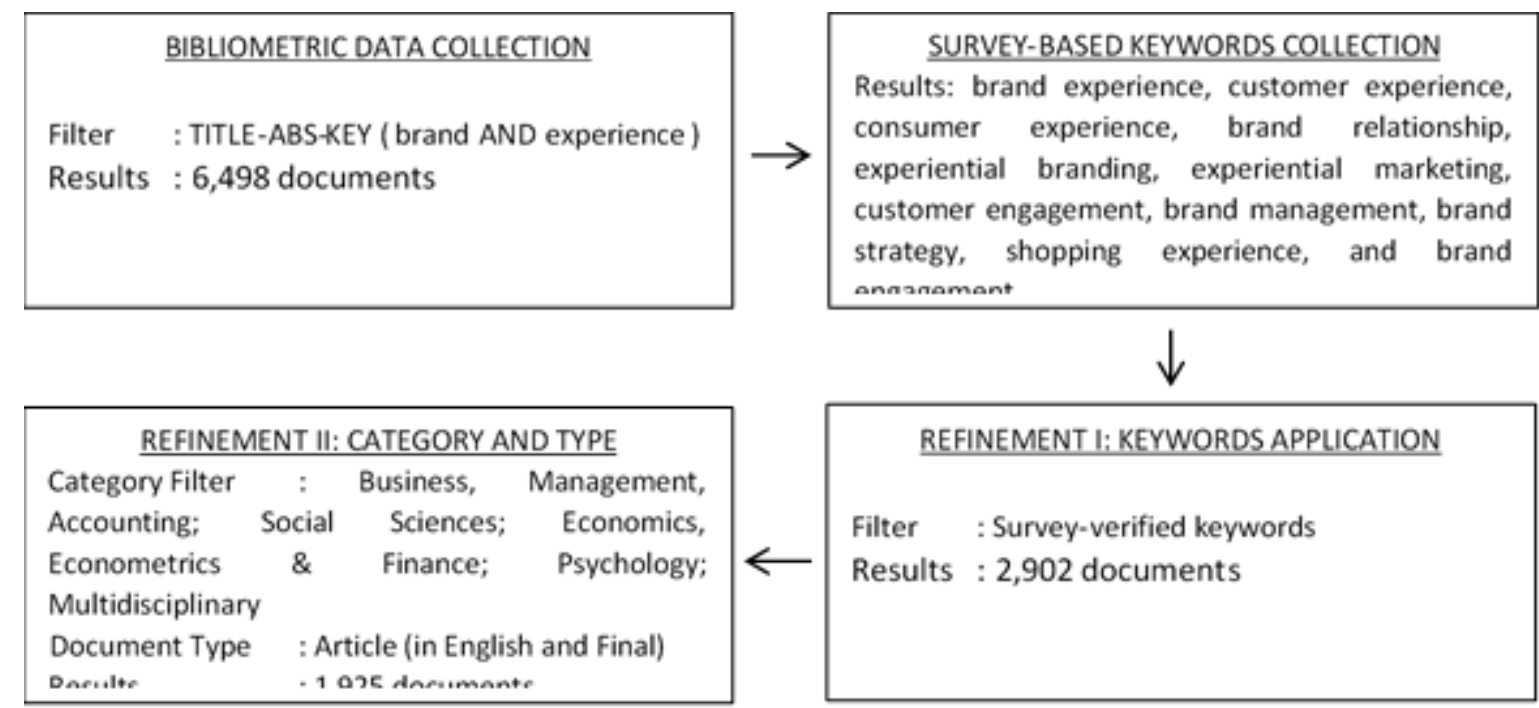

Figure 1. Data collection process

\section{Results and Discussion}

The bibliometric analysis shows that research trend on brand experience has been volatile for quite some times. There were years with no publication growth at all and years with significant increases. One 
important takeaway from the graph is the consistency of publication in years covered in this study. There was no year without publication and the annual number of papers was also on a positive trend.

Important milestones in brand experience research development could be seen from Figure 2. The biggest growth of brand experience publication happened in 1997 which marked by $300 \%$ increase. The reason for that significant growth might due to low publication number in the previous year. Another milestone has happened last year where the publication number topped the chart by 311 titles.

Interestingly, data collection from Scopus database indicated year of 1981 as the starting point of research publication on brand experience. This finding is different from Khan and Rahman's (2015) suggestion that brand experience concept was initiated by Ortmeyer and Huber in 1991. The only title that has been published on 1981 was written by Arndt and May entitled "the Hypothesis of a Dominance Hierarchy of Information Sources" and published on Journal of the Academy of Marketing Science.

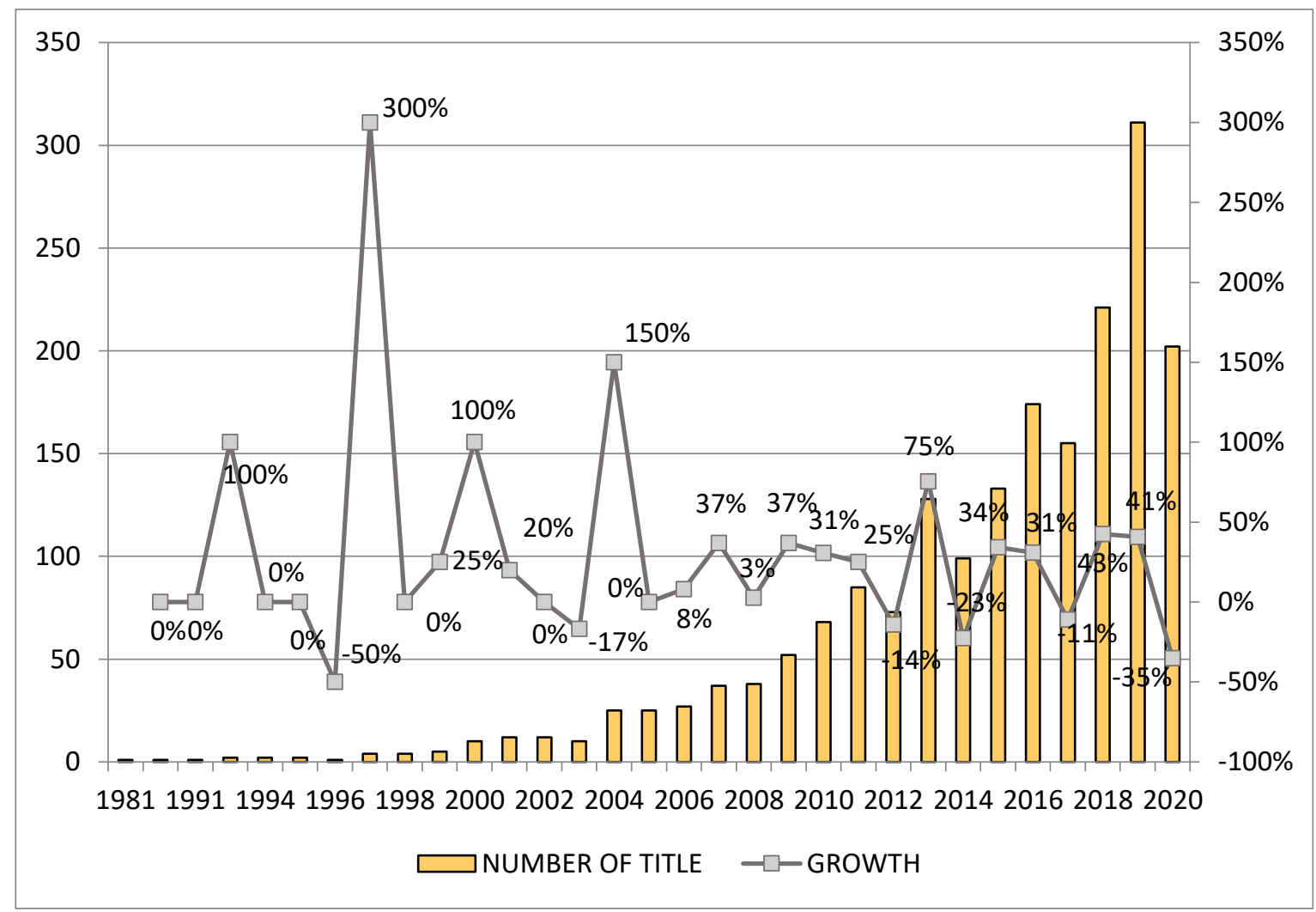

Figure 2. Yearly publication number and document growth

\subsection{Number of Papers and Citations}

Figure 3 compares the publication number of highly productive scholars on brand experience. During the publication years covered in this study, Khan, I. (Prince Sultan University, Saudi Arabia) has the biggest number of publications on brand experience. In addition, Rahman, Z. (Indian Institute of Technology Roorkee, India), Loureiro, S.M.C. (ISCTE - Instituto Universitario de Lisboa, Portugal) and King, C. (Temple University, United States) shared the same publication number of 12 articles. 


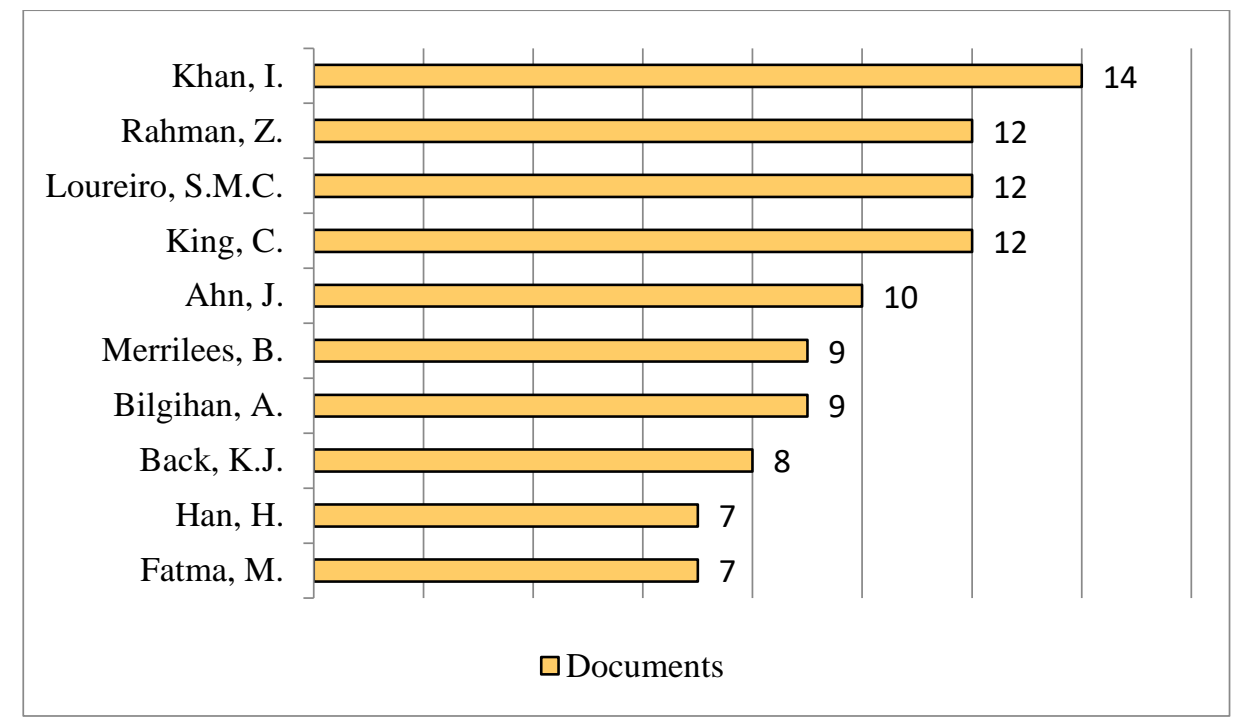

Figure 3. Documents by author

Citation-wise, Fournier's article entitled "Consumers and Their Brands: Developing Relationship Theory in Consumer Research" was the most cited articles of all time. The article that has been published in 1998 was cited 3,302 times. This record outnumbered the second most cited articles written by McAlexander, Schouten, and Koenig in 2002 by more than twice. Some might argue the high citation number is due to the year the article was published (i.e. the longer an article has been published, the more citation it can get). Although, in this context Fournier's article got more citation than any older article on the top ten list (Table 1).

Table 1. Top ten highly cited articles

\begin{tabular}{|c|c|c|c|c|}
\hline \multicolumn{5}{|c|}{ Top ten highly cited articles } \\
\hline No. & Authors & Title & Year & Citation \\
\hline 1 & Fournier S. & $\begin{array}{l}\text { Consumers and their brands: Developing } \\
\text { relationship theory in consumer research }\end{array}$ & 1998 & 3302 \\
\hline 2 & $\begin{array}{l}\text { McAlexander J.H., } \\
\text { Schouten J.W., Koenig } \\
\text { H.F. }\end{array}$ & Building brand community & 2002 & 1332 \\
\hline 3 & $\begin{array}{l}\text { Brakus J.J., Schmitt B.H., } \\
\text { Zarantonello L. }\end{array}$ & $\begin{array}{l}\text { Brand Experience: What Is It? How Is It } \\
\text { Measured? Does It Affect Loyalty? }\end{array}$ & 2009 & 1322 \\
\hline 4 & $\begin{array}{l}\text { Brodie R.J., Ilic A., Juric } \\
\text { B., Hollebeek L. }\end{array}$ & $\begin{array}{l}\text { Consumer engagement in a virtual brand } \\
\text { community: An exploratory analysis }\end{array}$ & 2013 & 1083 \\
\hline 5 & $\begin{array}{l}\text { Verhoef P.C., Lemon } \\
\text { K.N., Parasuraman A., } \\
\text { Roggeveen A., Tsiros M., } \\
\text { Schlesinger L.A. }\end{array}$ & $\begin{array}{l}\text { Customer Experience Creation: Determinants, } \\
\text { Dynamics and Management Strategies }\end{array}$ & 2009 & 1002 \\
\hline 6 & Vakratsas D., Ambler T. & $\begin{array}{l}\text { How advertising works: What do we really } \\
\text { know? }\end{array}$ & 1999 & 709 \\
\hline 7 & Thompson C.J. & $\begin{array}{l}\text { Interpreting consumers: A hermeneutical } \\
\text { framework for deriving marketing insights from } \\
\text { the texts of consumers' consumption stories }\end{array}$ & 1997 & 700 \\
\hline 8 & $\begin{array}{l}\text { Batra R., Ahuvia A., } \\
\text { Bagozzi R.P. }\end{array}$ & Brand love & 2012 & 613 \\
\hline
\end{tabular}




\begin{tabular}{lllll}
\hline 9 & Mollen A., Wilson H. & $\begin{array}{l}\text { Engagement, telepresence and interactivity in } \\
\text { online consumer experience: Reconciling } \\
\text { scholastic and managerial perspectives }\end{array}$ & 2010 & 502 \\
10 & Escalas J.E. & $\begin{array}{l}\text { Narrative Processing: Building Consumer } \\
\text { Connections to Brands }\end{array}$ & 2004 & 475 \\
\hline
\end{tabular}

\subsection{Sources of articles}

Research publications on brand experience have been published in hundreds of journals. Out of that range, the top five sources of articles have published more than 37 papers. Journal of Business Research was the biggest contributor of brand experience publication with 83 titles and generated 5,010 citations (see Table 2). Compared to the second and third biggest sources of articles, Journal of Business Research's number of articles was significantly higher.

Data from Table 2 indicated a pattern that the higher the number of a title, the higher the citation number a journal could get. However, there was an anomaly for Journal of Retailing and Consumer Services. Although it has published 62 articles on brand experience, which was significantly higher than its follower, the journal recorded lowest number of citations of all article sources.

We can get better perspective about the finding by looking at Figure 4. It depicts document growth of the most productive sources of articles. The graph indicates number of publications on brand experience began to spark after 2005. Journal of Retailing and Consumer Services, in particular, has gotten its traction in the last few years. For instance, brand experience publication in the journal increased from only two titles in 2017 to 10 in 2018 and to 16 in 2019. The increase was significant for such short period of time and the citation collected might not as fast as the publication speed.

Table 2. Top five most productive sources of articles

\begin{tabular}{clccc}
\hline \multicolumn{5}{c}{ Sources of Articles (Highest Publication Number) } \\
\hline \multirow{2}{*}{ No. } & \multicolumn{1}{c}{ Journal } & $\begin{array}{c}\text { Number of } \\
\text { Title }\end{array}$ & $\begin{array}{c}\text { Citations to } \\
\text { Date }\end{array}$ & $\begin{array}{c}\text { Impact Factor } \\
2019 *\end{array}$ \\
\hline 1 & Journal of Business Research & 83 & 5010 & 7.161 \\
\hline 2 & Journal of Product and Brand Management & 65 & 2168 & 3.034 \\
3 & Journal of Retailing and Consumer Services & 62 & 814 & 5.792 \\
4 & Journal of Brand Management & 48 & 2049 & 2.329 \\
5 & International Journal of Contemporary Hospitality & 37 & 1131 & 7.065 \\
\hline
\end{tabular}

*Based on Scimago Journal \& Country Rank (2-year basis, equivalent to Thomson-Reuters impact factor) 


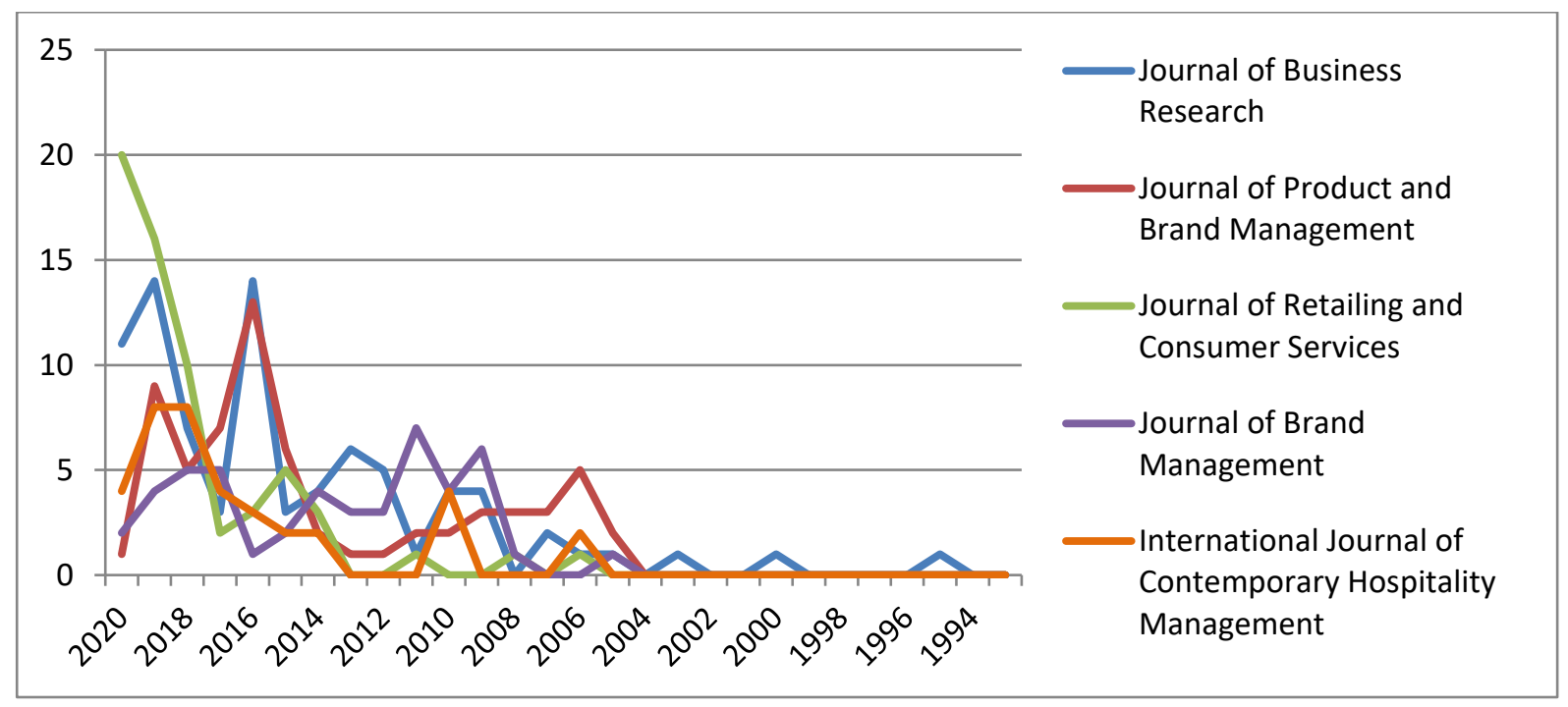

Figure 4. Document growth of five most productive sources of articles

\subsection{Countries and institutions}

The majority of research publications on brand experience have come from the United States. No less than 578 articles have been published by researchers from the country. This record was the largest and put of all other countries aside. Compared to the United Kingdom that has managed to publish 237 articles and Australia with 136 articles (see Figure 5), the United States's number of publications was out of reach. It has left the second largest publishing country by more than twice.

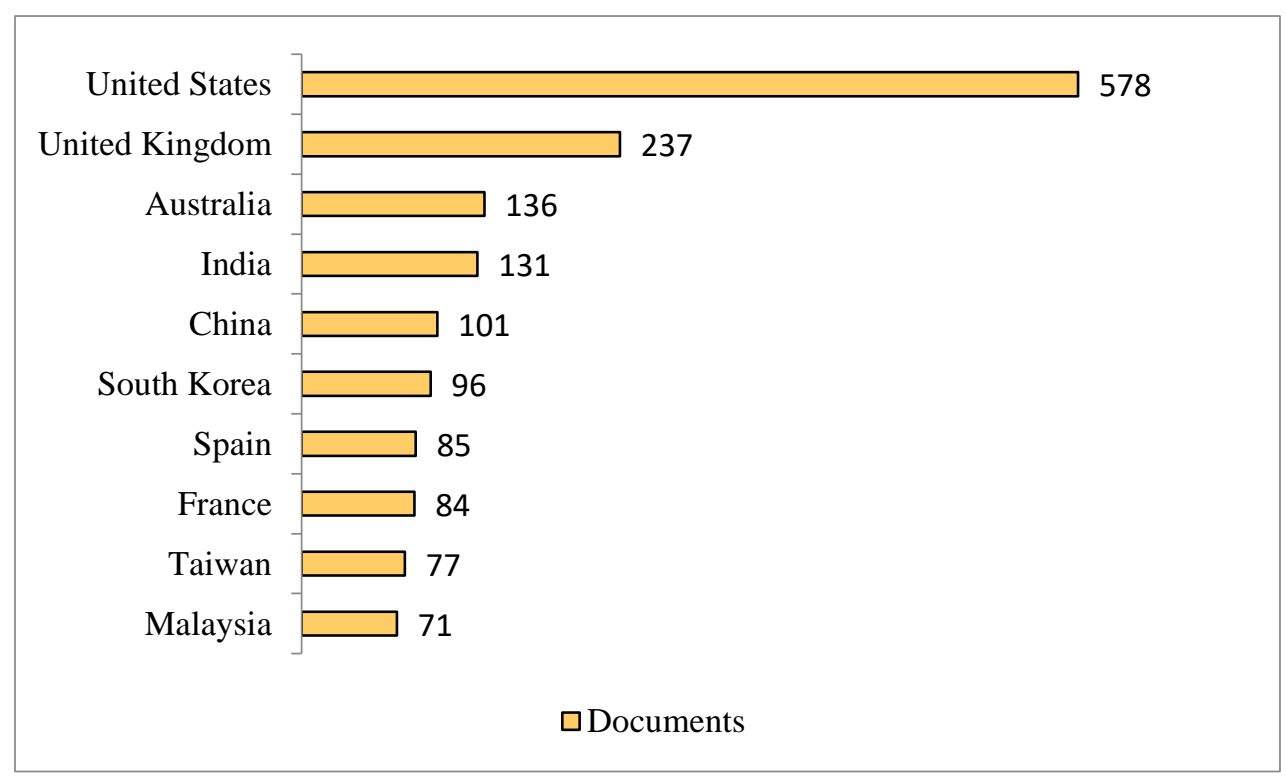

Figure 5. Top 10 number of documents (country) 


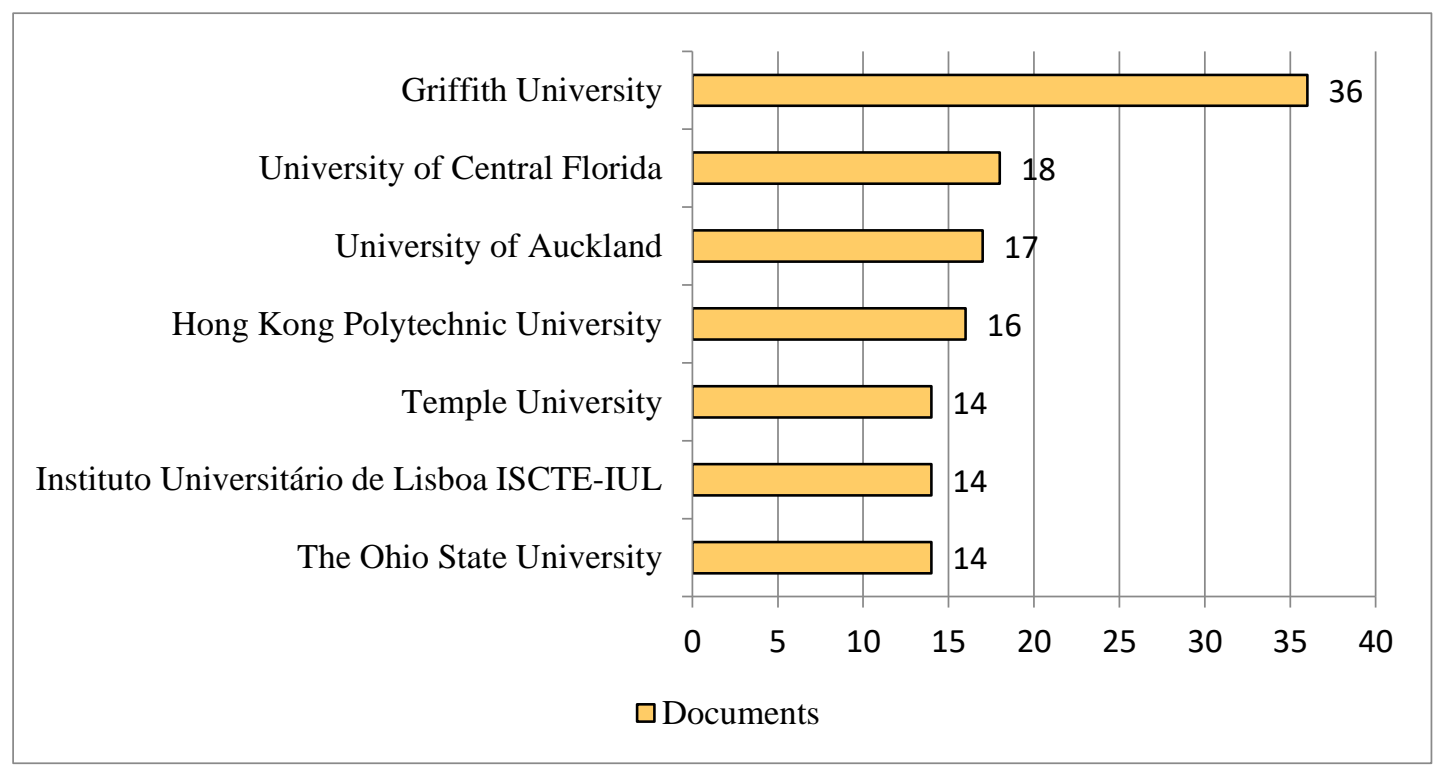

Figure 6. Top institutions on brand experience research publications

Different angle from institutional perspective brought an interesting finding. Previously we understand that the United States held the best record for country-level publications. However, the first country position does not necessarily have the ability to opt for the first institution of largest publication. A closer look from institutional perspective has put a university from another country under the spotlight. The bibliometric analysis revealed Griffith University in Australia as the affiliated institution with the biggest publication number on brand experience. The university rendered 36 articles and it is twice of University of Central Florida that has second highest record of 18 (see Figure 6).

\subsection{Authors'keywords}

Keywords identification is critical in literature query and knowledge mapping of bibliometric analyses ( $\mathrm{Li}, 2018)$. Table 4 indicated top frequent keywords used by scholars in their brand experience publications. The table has two main sections: top 10 individual keywords on the left side and two-word common phrases on the right side. Word "brand" has the highest frequency of 1,614 uses. That record is three times higher than the second word "experience".

Combined together, those two words made up an expression that topped the two-word phrases frequency as shown on the right side of Table 4. Expression "brand equity" took the second place with 141 expression count and "brand loyalty" was following with 112 expression count. The keywords and phrases were extracted from research publications collected and analysed through online word processing tool.

Table 4. Authors' top keywords

\begin{tabular}{lclc}
\hline \multicolumn{2}{c}{ Top 10 words frequency: } & \multicolumn{2}{c}{ Two-word phrases frequency: } \\
\hline \multicolumn{1}{c}{ Keyword } & Uses & \multicolumn{1}{c}{ Keyword } & Uses \\
brand & 1614 & brand experience & 223 \\
experience & 504 & brand equity & 141 \\
customer & 371 & brand loyalty & 112 \\
consumer & 333 & customer experience & 89 \\
social & 333 & brand image & 87 \\
marketing & 300 & consumption behavior & 77 \\
\hline
\end{tabular}




\begin{tabular}{llll}
\hline loyalty & 214 & brand management & 73 \\
branding & 205 & consumer behaviour & 72 \\
online & 177 & social media & 71 \\
behavior & 173 & customer satisfaction & 53 \\
\hline
\end{tabular}

\section{Conclusions}

This study set out to provide research publication trends and to complete and complement existing limited bibliometric studies on brand experience. The analysis has shown that academic publications on brand experience have been increasing from time to time, especially after 2005. Another significant increase happened in 1997 where the publication number went up three times.

The most cited article is written by Fournier entitled "Consumers and Their Brands: Developing Relationship Theory in Consumer Research." The article was published in 1998 and, as the cut off of this study, has been cited 3,302 times. Journal of Business Research has 83 published titles on brand experience and collected 5,010 citations. The achievement has put the journal as the most productive source of publication.

The United States has become the country origin of most articles related to brand experience with a record of 578 titles. It left the United Kingdom at the second with 237 titles and Australia at the third with 136 titles. Griffith University is the only university that outnumbered any other institutions in terms of publication number with a record of 36 titles.

\section{Limitations}

This study used statistical information of published articles on Scopus database and hence excluded other non-Scopus indexed articles. The articles were retrieved using keyword equation that has been verified by scholars through online survey. Nonetheless, the application of different keywords or different order in keyword equation may return different results. Furthermore, the length of publication period may affect citation number of an article. The chance of older articles to get cited is bigger than the recent ones.

\section{References}

Brakus, J. J., Schmitt, B. H., \& Zarantonello, L. (2009) 'Brand Experience: What Is It? How Is It Measured? Does It Affect Loyalty?', Journal of Marketing, Vol. 73, No. 3, pp.52-68.

Elisabetta, R., Gabriele, M., Massimo, S., Sofia, B., \& Giuseppe, S. M. (2018) 'Structural Trend and Conceptual Evolution of Research on Genetically Modified Organisms Using a Science Mapping Approach', Journal of Cleaner Production, Vol. 205, pp.329-338.

Gaviria-Marin, M., Merigo, J. M., \& Popa, S. (2018), 'Twenty Years of the Journal of Knowledge Management: A Bibliometric Analysis', Journal of Knowledge Management, Vol. 22, No. 8, pp.1655-1687.

Geng, Y., Chen, W., Liu, Z., Chiu, A. S., Han, W., Liu, Z., et al. (2017), 'A Bibliometric Review: Energy Consumption and Greenhouse Gas Emissions in the Residential Sector', Journal of cleaner production, Vol. 159, pp.301-316. 
Gentile, C., Spiller, N., \& Noci, G. (2007), 'How to Sustain the Customer Experience: An Overview of Experience Components that Co-create Value With the Customer', European Management Journal, Vol. 25, No. 5, pp.395-410.

Hoch, S. J. (2002), 'Product Experience is Seductive', Journal of Consumer Research, Vol. 29, No. 3, pp.448-454.

Holbrook, M. B., \& Hirschman, E. C. (1982), 'The Experiential Aspects of Consumption: Consumer Fantasies, Feelings, and Fun', Journal of Consumer Research, Vol. 9, No. 2, pp.132-140.

Hui, M. K., \& Bateson, J. E. (1991), 'Perceived Control and the Effects of Crowding and Consumer Choice on the Service Experience', Journal of Consumer Research, Vol. 18, No. 2, pp.174-184.

Iglesias, O., \& Singh, J. J. (2011), 'The Role of Brand Experience and Affective Commitment in Determining Brand Loyalty', Brand Management, Vol. 18 No. 8, pp.570-582.

Kerin, R. A., Jain, A., \& Howard, D. J. (1992), 'Store Shopping Experience and Consumer PriceQuality-Value Perceptions’, Journal of Retailing, Vol. 68 No. 4, pp.376-397.

Khan, I., \& Rahman, Z. (2015), 'A Review and Future Directions of Brand Experience Research,' International Strategic Management Review, Vol. 3, No. 1-2, pp.1-14.

Li, M. (2018), 'Classifying and Ranking Topic Terms Based on A Novel Approach: Role Differentiation of Author Keyword’, Scientometrics, Vol. 166, pp.77-100.

Morrison, S., \& Crane, F. G. (2007), 'Building the Service Brand by Creating and Managing an Emotional Brand Experience', Journal of Brand Management, Vol. 14, No. 5, pp.410-421.

Nysveen, H., Pedersen, P. E., \& Skard, S. (2013), 'Brand Experiences in Service Organizations: Exploring the Individual Effects of Brand Experience Dimensions', Journal of Brand Management, Vol. 20, No. 5, pp.404-423.

Villa, E., Ruiz, L., Valencia, A., \& Picon, E. (2018), 'Electronic Commerce: Factors Involved in its Adoption from a Bibliometric Analysis', Journal of Theoretical and Applied Electronic Commerce Research, Vol. 13, No.1, pp.39-70.

Zarantonello, L., \& Schmitt, B. H. (2010), 'Using The Brand Experience Scale To Profile Consumers And Predict Consumer Behaviour', Journal of Brand Management, Vol. 17, No. 7, pp.532 - 540.

Zupic, I., \& Cater, T. (2015), 'Bibliometric Methods in Management and Organization', Organizational Research Methods, Vol. 18, No. 3, pp.429-472.

Zha, D., Melewar, T. C., Foroudi, P., \& Jin, Z. (2020). An Assessment of Brand Experience Knowledge Literature: Using Bibliometric Data to Identify Future Research Direction. International Journal of Management Reviews. Vol. 0, pp.1-31. 
Pengalaman Merek: Tinjauan dari 39 Tahun Pengembangan Riset

\begin{abstract}
Abstrak
Studi ini mengeksplorasi tren penelitian akademis tentang pengalaman merek menggunakan metode bibliometrik. Eksplorasi termasuk data statistik dari artikel yang diterbitkan di database Scopus. Artikel yang relevan diekstrak dari jurnal terindeks Scopus menggunakan kata kunci yang dikumpulkan melalui survei online. Analisis tersebut mencakup 1.920 artikel di 484 jurnal yang diterbitkan antara tahun 1981 dan 2020. Studi ini mengenali para sarjana, institusi, sumber, serta artikel penelitian pengalaman merek terkemuka yang paling banyak dikutip. Beberapa kata kunci penting dan paling sering digunakan dalam publikasi pengalaman merek juga diidentifikasi. Temuan studi menunjukkan minat yang meningkat pada penelitian pengalaman merek meskipun tidak ada publikasi di beberapa tahun awal perkembangannya. Artikel yang paling banyak dikutip ditulis oleh Fournier pada tahun 1998 berjudul "Konsumen dan Mereknya: Teori Hubungan yang Berkembang dalam Riset Konsumen". Jurnal Riset Bisnis merupakan jurnal yang paling banyak dikutip di wilayah ini dengan 5.010 sitasi dan menjadi jurnal paling produktif dengan 83 judul.
\end{abstract}

Kata kunci: pengalaman merek; pengalaman pelanggan; pemasaran berdasarkan pengalaman; tren penelitian; analisis bibliometrik 